\title{
PEMBERDAYAAN KELOMPOK MASYARAKAT MELALUI PENGEMBANGAN AGROINDUSTRI DI DESA MANDING TIMUR KECAMATAN MANDING
}

\author{
Moh. Kurdi ${ }^{1}$, Fatmawati ${ }^{2}$ \\ ${ }^{1)}$ Dosen Fakultas Ekonomi dan Bisnis Universitas Wiraraja \\ ${ }^{2)}$ Dosen Fakultas Pertanian Universitas Wiraraja \\ Email: ${ }^{1)}$ mkurdi@wiraraja.ac.id, ${ }^{2)}$ fatmawati@wiraraja.ac.id
}

\begin{abstract}
ABSTRAK
Desa Manding Timur berada di Kecamatan Manding Kabupaten Sumenep. Masyarakat di Desa Manding Timur selain menjadi pegawai, pedagang dan petani mempunyai pekerjaan lain sebagai pengusaha makanan olahan (Agroindustri). Diantara produk olahannya yang ada antara lain keripik pisang dan keripik singkong. Permasalahan yang dihadapi masyarakat Desa Manding Timur adalah rendahnya penguasanaan teknologi dan manajamen usaha masih rendah yang meliputi aspek administrasi keuangan, manajemen mutu dan manajemen pemasaran. Pada Agroindustri $80 \%$ sistem administrasi keuangan belum tertata dengan baik dan masih banyak produk yang dihasilkan dengan kemasan yang masih sederhana sehingga kurang menarik dan kurang aman dari bahaya biologi, kimia dan fisik. Untuk jaminan mutu produk perlu adanya penyuluhan atau pengetahuan kemasan standar produk UMKM Agroindustri dan pemberian alat pengemasan. Diharapkan produk Agroindustri Desa Manding Timur mampu bersaing di tingkat regional dan nasional.Hasil program pengabdian masyarakat adalah 1) Pengrajin diberi pelatihan pembuatan laporan keuangan yang sederhana, dan pengrajin sudah mulai menerapkan pembukuan yang benar, 2) pengrajin diberi pelatihan cara pengemasan yang tepat dan dibuatkan label untuk merk produknya agar produknya tidak mudah rusak dan menarik konsumen.Pelaksanaan pemberdayaan masyarakat melalui pengembangan agroindustri di Desa Manding Timur Kecamatan Manding berjalan baik, dengan kegiatan pendampingan dan pelatihan pembuatan laporan keuangan sederhana serta pelatihan pengemasan dan penyerahan sealer serta plastik berbagai jenis yang dapat digunakan untuk mengemas produk para pengrajin. Peserta dalam kegiatan pengabdian memberikan tanggapan yang sangat baik dengan berpartisipasi mengikuti kegiatan secara tekun. Selain itu menyampaikan apresiasi kepada Tim Pelaksana karena telah memberikan pendampingan terhadap para pengrajin sehingga dapat menambah ketrampilan pengrajin untuk memajukan usahanya.
\end{abstract}

Kata kunci: Keripik, Kelompok Masyarakat, Agroindustri

\section{PENDAHULUAN}

Desa Manding Timur berada di bagian utara dari Kecamatan Manding perbatasan dengan Desa Manding Daya, Desa Manding Laok, Desa Giring dan Kecamatan. Desa Manding Timur terbagi dari 5 dusun 5 rukun warga dan 24 rukun tetangga. Desa Manding Timur mempunyai wilayah dengan luas sebesar 332.24 ha yang terdiri dari pekarangan, perkebunan, ladang, dan persawahan (BPS, 2018).
Mata pencaharian sampingan sebagian masyarakat Desa Manding Timur adalah sebagai pengrajin makanan olahan (Agroindustri), sedangkan petani sebagai pekerjaan utama meraka. Beberapa produk olahannya antara lain keripik pisang dan keripik singkong. Pengrajin belum menerapkan sistem administrasi keuangan dengan benar sehingga kemajuan usaha tidak jelas. Kemasan produk yang dihasilkan masih sederhana belum memenuhi standard kemasan. 
Keripik khas Desa Manding Timur sudah banyak dikenal oleh masyarakat luas, namun cara pengelolaan manajemen masih jauh dari baik terutama dalam keuangan, sehingga antara modal usaha dan keluarga tidak dapat diketahui dengan pasti. Sehingga dengan adanya bantuan pendampingan dan pelatihan manajemen keuangan yang baik dapat menjadikan pengelolaan usaha lebih professional dan baik.

Selain itu kemasan yang digunakan juga masih sangat sederhana, salah satunya adalah yang dilakukan oleh ibu Subaida. Sehingga perlu adanya pelatihan dan pendampingan terhadap pengelolaan manajemen dan cara pengemasan yang baik.

Usaha yang dilakukan oleh ibu Subaida pada awalnya hanya iseng dan untuk membantu perekonomian keluarga, namun dengan berjalannya waktu permintaan keripik pisang dan singkong mulai dikenal masyarakat. Selama ini pemasaran produk masih berdasarkan pesanan dan dititipkan teman atau saudara. Kemasan produk juga menjadi kendala dalam pemasaran.

Kemasan produk masih sangat sederhana dengan hanya menggunakan kantong plastik dan label stiker. Hal ini mengindikasikan bahwa kemasan dan metode pelabelan kurang sesuai dengan pangsa pasar produk pada saat ini. Selain itu, sampai saat ini masih belum memiliki mesin sealer, sehingga yang digunakan masih meminjam dari saudara maupun tetangga sehingga dapat mengganggu kelancaran proses produksi. Diharapkan dengan adanya pendampingan dan pelatihan dapat mengembangkan wilayah pemasaran yang diikuti dengan perbaikan pelabelan yang baik dan lebih menarik.

\section{METODE}

Dari hasil uraian permasalah yang dipaparkan di atas, maka solusi yang akan dilakukan dalam pelaksanaan kegiatan pengabdian ini sebagai berikut :

a. Usaha pengolahan hasil yang dilakukan masyarakat belum menggunakan sistem administrasi yang benar. Pelaku usaha belum pernah melalukan pencatatan setiap kegiatan dalam usaha baik tentang pemasukan dan pengeluaran keuangan. Bahkan yang mereka lakukan tidak memisahkan antara keuangan usaha dengan keuangan keluarga yang menjadikan perkembangan usaha tidak dapat diketahui secara pasti.

b. Dalam melalukan kegaiatan usaha juga dibutuhkan manajemen mutu, maka dari itu perlu adanya pelatihan manajeman mutu sehingga produk yang dihasilkan sesuai dengan standar baik dari produk itu sendiri maupun dari cara pengemasan. Pengemasan yang baik tidak akan mudah terkontaminasi dengan bahan bahaya dari luar. Seperti halnya bhaya kimia, biologi dan perubahan fisik. Bahkan dari produk yang dihasilkan belum mempunyai merek dagang.

Untuk mencapai target dalam pelaksanaan kegiatan ini, berikut beberapa maka langkah dan cara dalam pelaksanaan kegiatan pengabdian ini, yaitu:

a. Manajemen Keuangan

1) Sosialisasi sistem administrasi keuangan

2) Pendampingan pembuatan laporan keuangan

b. Manajemen Mutu Produk Makanan Olahan

c. Pelatihan cara pembuatan kemasan yang baik dan benar.

\section{HASIL DAN PEMBAHASAN}

Program pelaksanaan pengabdian kepada masyarakat ini mulai dilakukan dengan melakukan koordinasi dengan pihak mitra dan perangkat desa. Koordinasi ini dilakukan sebagai upaya untuk menjalin komunikasi yang baik dan kerjasama yang 
bisa dilakukan secara berkesinambungan. Tahap selanjutnya dalam pelaksanaan program ini yaitu persiaapan sarana dan prasarana serta bahan-bahan yang dibutuhkan dalam kegiatan. Kegiatan ini dilakukan dari tanggal 6 - 29 Mei 2019.

Tahap berikutnya adalah persiapan materi pelatihan, hal inipenting dilakukan agar waktu pelaksanaan pelatihan dan penyampaian materi dapat berjalan dengan baik serta lancar. Persiapan materi ini dilakukan dari tanggal 3 - 20 Juni 2019.

Untuk kegiatan selanjutnya pelatihan pembuatan laporan keuangan sederhana bertempat di UKM Surya Abadi Desa Manding Timur Kecamatan Manding pada hari Sabtu tanggal 22 Juni 2019. Pelatihan pembuatan laporan keuangan tersebut dilakukan oleh tim pelaksana pengabdian Universitas Wiraraja yang terdiri dari Moh. Kurdi, SP., MM Prodi Manajemen Fakultas Ekonomi dan Bisnis dengan kompetensi Manajemen Strategi dan Ir. Fatmawati, MP Prodi Agribisnis Fakultas Pertanian dengan kompetensi bidang Agribisnis.

Pertanyaan yang diajukan cukup banyak oleh peserta yang berkaitan dengan teknis pembukuan. Materi yang disampaikan saat pelatihan terkait bagaimana cara membuat pembukuan keuangan yang sederhana dan buku tentang persediaan barang.Pada saat pelaksanaan kegiatan langsung dilakukan praktek pembuatan pencatatan keuangan dan buku persediaan barang. Setelah pelaksanaan kegiatan program pelatihan, tim pengabdian tetap melakukan monitoring terhadap perkembangan dan aplikasi materi yang sudah didapatkan oleh peserta.

Pada saat bulan pertama dari pelaksanaan pelatihan, pembuatan laporan pembukuan keuangan dapat dilakukan degan baik dan rutin, tetapi untuk bulan kedua dan berikutnya sudah tidak laksanakan dengan rutin. Hal ini yang selalu menjadi kendala bagi mitra untuk mendokumen laporan keuangan.

Pada kegiatan pengabdian juga diperkenalkan mengenai pengemasan dan penyerahan sealer sebagai alat pengemasan dan berbagai jenis plastik yang dapat digunakan untuk kemasan. Kegiatan dilakukan pada hari Kamis 27 Juni 2019 jam yang diawali dengan pemberian materi yang berkaitan dengan kemasan.

Pemberian materi ini dilakukan untuk menumbuhkan ide kreatif dengan mengaiktkan struktur, bentuk, warna, material, dan citra dengan elemen desain dapat menginformasikan produk.

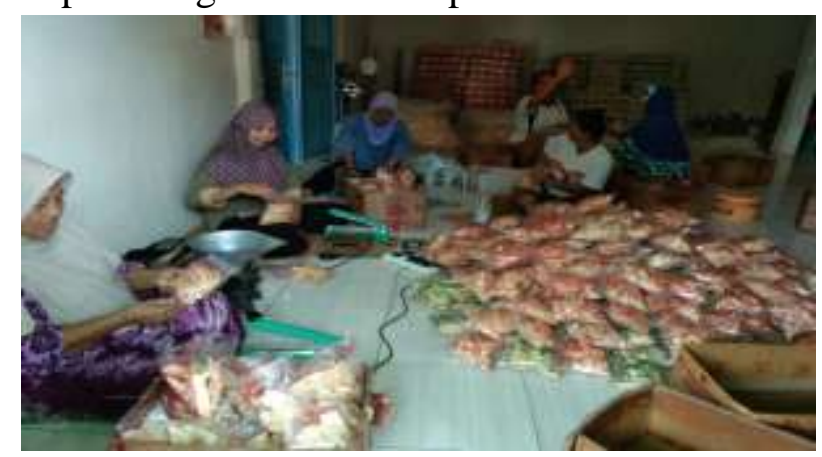

Gambar 1. Proses Pengemasan Produk Keripik

Setelah selesai penyampaian materi, kemudian dilanjutkan penyerahan alat bantuansealer untuk mengemas produk. Proses penyerahan sealer langsung diberikan oleh Ketua Tim yaitu Moh. Kurdi, SP., MM. dengan adanya bantuan sealer harapannya dapat digunakan untuk proses proses pengemasan produk keripik pisang dan singkong.

Tim pelaksana tetapi melakukan monitoring dan pendampingan, baik untuk pembukuan keuangan, pencatatan ketersediaan barang dan pengemasan produk. Hal ini dilakukan sebagai bentuk keberlanjutan program kegiatan pelaskanaan pengabdian kepada masyarakat. 


\section{SIMPULAN}

Pelaksanaan pengabdian kepada masyarakat melalui pemberdayaan pengembangan agroindustri di Desa Manding Timur Kecamatan Manding berjalan baik, dengan kegiatan pendampingan dan pelatihan pembuatan laporan keuangan sederhana serta pelatihan pengemasan dan penyerahan sealer serta plastik berbagai jenis yang dapat digunakan untuk mengemas produk para pengrajin. Peserta dalam kegiatan pengabdian memberikan tanggapan yang sangat baik dengan berpartisipasi mengikuti kegiatan secara tekun. Selain itu menyampaikan apresiasi kepada Tim Pelaksana karena telah memberikan pendampingan terhadap para pengrajin sehingga dapat menambah ketrampilan pengrajin untuk memajukan usahanya.

\section{DAFTAR PUSTAKA}

Badan Pusat Statistik Kabupaten Sumenep. 2018. Kecamatan Manding dalam Angka 2018.Sumenep : Badan Pusat Statistik.

Wijantri Kusumadati, Siti Zubaidah, Hastin Ernawati Nur Chusnul Chotimah. 2016. IbM Kelompok Pembuat Produk Olahan Ubi Kayu Di Kota Palangka Raya. Universitas Palangkaraya. 